\title{
The Changing Landscape of the Malay Gamelan and its Implications on Music Education in Malaysia
}

\author{
Shahanum Mohd Shah, Janette Jannah Poheng \\ Faculty of Music, Universiti Teknologi MARA, Selangor 40450, Malaysia \\ shahanum@uitm.edu.my, janette@uitm.edu.my \\ Tel of 1 st Author: +60122831351
}

\begin{abstract}
Globalisation and information technology have posed challenges to cultural systems whereby new ways are taking over old ways that are indigenous to a particular culture. Traditional modes of cultural expression are being restructured where changes in musical practices and sound systems are affecting composers to remain vital. New music for the Malay gamelan using new modes of expression require schools to act as agents for change and innovation to occur. This study examines the direction gamelan music is taking in Malaysia and its implications on music education in Malaysia in order for the gamelan to remain relevant.
\end{abstract}

Keywords: Malay gamelan; teaching; learning; approaches

eISSN: 2398-4287 ( 2021.. The Authors. Published for AMER ABRA cE-Bs by e-International Publishing House, Ltd., UK. This is an open access article under the CC BYNC-ND license (http://creativecommons.org/licenses/by-nc-nd/4.0/). Peer-review under responsibility of AMER (Association of Malaysian Environment-Behaviour Researchers), ABRA (Association of Behavioural Researchers on Asians) and cE-Bs (Centre for Environment-Behaviour Studies), Faculty of Architecture, Planning \& Surveying, Universiti Teknologi MARA, Malaysia.

DOI: https://doi.org/10.21834/ebpj.v6iSl5.2939

\subsection{Introduction}

Modernisation is posing a significant challenge to cultural systems. New ways are taking over old ways that are indigenous to a particular culture. Globalisation and the information revolution seem to have become the order of the day, and music has not been spared this phenomenon. Traditions are having to adapt to new forces to remain vital. Traditional modes of cultural expression are being restructured were changes in musical practice, and sound systems are affecting composers. The new ideas and trends of music-making that are appearing are causing traditional ways to persist by interacting with current trends. Englis (2003) describes the emerging ideas as "localising the global" or "globalising the local". Such music-making is gaining ground and becoming evident in the contemporary soundscapes of non-western countries like Southeast Asia.

Musicians are creating new modes of expression using the gamelan, which are attracting listeners from even the younger generation. Instrumental combinations, musical structures and textures from the diverse cultures of Malaysia and the world have become the vocabulary of new gamelan music that reflects the cultural diversity of the region. New playing techniques, functions and symbolic meanings have emerged.

The gamelan was brought to Malaysia from Indonesia in the 1800s, and performances were restricted to the royal courts. When the gamelan was allowed to be performed in public in the 1970s (Matusky \& Tan, 1997), the gamelan became accessible, traditions were broken, and the gamelan was learned and performed by people outside the royal courts. This led to developments and innovations taking place, which is evident in current practices. These changes are seen in the use, sound and concept of the gamelan instrument as well as social and musical contexts caused by many factors such as globalisation.

eISSN: 2398-4287 ( 2021.. The Authors. Published for AMER ABRA cE-Bs by e-International Publishing House, Ltd., UK. This is an open access article under the CC BYNC-ND license (http://creativecommons.org/licenses/by-nc-nd/4.0/). Peer-review under responsibility of AMER (Association of Malaysian Environment-Behaviour Researchers), ABRA (Association of Behavioural Researchers on Asians) and cE-Bs (Centre for Environment-Behaviour Studies), Faculty of Architecture, Planning \& Surveying, Universiti Teknologi MARA, Malaysia.

DOI: https://doi.org/10.21834/ebpj.v6iSl5.2939 
The purpose of this study was to examine the changes that have taken place in Malay gamelan music and the implications on music education in Malaysia. Gamelan music in Malaysia has crossed traditional boundaries in the past few decades (Tan, 2008). New music for the gamelan is attracting listeners to a traditional art that was on the verge of extinction.

\subsection{Literature Review}

"Gamelan," a Javanese word whose root word "gamel" means to strike a percussive musical instrument, refers to an ensemble of percussion musical instruments. According to Nasuruddin (1994), although the gamelan originated in Indonesia, it could, however, be viewed as a common heritage of the old Malay world, which consisted of the geographical delineations encompassing present-day Indonesia, Malaysia, Philippines, Thailand, Cambodia, and parts of Vietnam. Similar gamelan ensembles and their variations that have been modified as a result of acculturation into the local environment are found in this region.

The music of the gamelan is most closely associated with Indonesia and Malaysia. The gamelan ensembles of Peninsular Malaysia were derived from Indonesia. Although there are many types of gamelan in the Malay Archipelago, the Malay gamelan is the legacy of the Peninsula Malays. They were brought by immigrants who came to Malaysia from the time of the Sri Vijaya and Majapahit empires. This gamelan, gamelan Jawa, is located in the southern state of Johor. The Malay Gamelan (Gamelan Melayu) as it is known today had its beginnings in the early 19th century when the states of Johor, Pahang, and Terengganu were under the suzerainty of Rhiau-Lingga or Johor-Rhiau (Matusky \& Tan, 1997). The gamelan originated from the Court of the Malay Sultanate of Rhiau-Lingga. It is presumed that the intermarrying of Javanese and Malay royal families seemed to be the way the gamelan was introduced to Malaysia from Java as the Malay gamelan was known in the courts of the Malay Sultans.

A basic gamelan ensemble used in Malaysia today typically comprises eight instruments, each with its own musical function. The instruments are the bonang barung, saron peking, saron barung, saron demung, gambang, kenong, a pair of gongs and the gendang (drum). The melody (main and ornamented) is played by the bonang, saron, and gambang; the gong acts as a punctuating instrument that marks the structure of a composition, and the gendang is the rhythmic instrument of the ensemble. The Malay gamelan uses a fivetone pentatonic tuning system, usually in the key of $\mathrm{C}$ or $\mathrm{Bb}$ Major. The traditional repertoire is basically heterophonic in texture as there is the main melody played simultaneously with ornamented versions of the melody in the melody part (Matusky, 2008).

The increase in awareness of the gamelan in recent years has had a positive effect on the position of traditional music in Malaysia. Having been under foreign rule for over 400 years, Malaysia was rapidly westernising at the expense of its own traditions. Knowledge of gamelan music spread through the organisation of music programs, new ensembles, festivals, workshops, and symposiums fostered the cultural identity of the people. More people are becoming conscious of their traditions and looking for ways to maintain those traditions. Composers are also starting to take a keen interest in composing for the gamelan ensemble, and new repertoire and performance styles result from their creative impulses. Together, these educational programs and compositions make available an unprecedented variety of musical sounds and also leads to an increase of gamelan repertoire. The changes in the musical style, repertoire content and attitudes toward the gamelan can be related to changes in the Malaysian culture or society and to changes in the ideas held by the people and the meanings they assign to their culture. For example, traditionally, males play the gamelan instruments while the dancers are females. We now see a situation whereby females are playing the gamelan. Nik Mustapha sees the involvement of both genders as a result of the evolution of status and also to fill the present needs of the development of traditional music and the wants of people to try something new.

\subsection{Methodology}

This study used ethnographic research and interviews as a means of collecting data. Methods included:

\subsection{Desk work}

Desk work involved documentation, transcription and analysis of selected repertoire, and drawing of conclusions.

\subsection{Fieldwork}

The fieldwork comprised the gathering of recordings and the direct context with the particular music that is being studied. Data for this study was conducted in Kuala Lumpur and Selangor, Malaysia, where gamelan activities are the most active. The method of research work included interviews held with practitioners and composers in Malaysia and participant observation which included learning of the gamelan, observation of performances, and being a participant-observer during gamelan rehearsals and documentation (audiovisual, sound recording, photography).

\subsection{Findings}

Current practices in contemporary Malay gamelan music indicate new ideas of using and playing the gamelan, which could increase the appeal of the ensemble. Many composers are experimenting with the unprecedented variety of musical sounds that can be obtained from the gamelan. Techniques other than the ones used to play traditional repertoire are being used. This is seen in the way the instruments are played both stylistically and technically and how the gamelan is being used to explore the possibilities in a range of colour, melody, tonal ability, and expression. 
The basic set of gamelan used in the royal palaces is thought to have comprised of the following instruments: saron barong, saron peking, gambang, kenong (3), bonang/kromong, gendang and gong agung and gong suwukan. With the development of the gamelan, new instruments were added to the ensemble. In present-day gamelan ensembles, certain groups are using an expanded version of the gamelan ensemble. This is done by doubling certain instruments and using instruments not in the basic original set. For example, in the traditional gamelan layout, one saron each and the bonang barong would suffice to play the traditional repertoire. Now, a set-up might include two saron barong and two saron peking for each to play different parts. Additional instruments also include the full range of kempul (small gongs), slenthem ad bonang penerus.

When the Malay gamelan became public, some traditional conventions were changed. In the earlier days, the gamelan musicians only consisted of men, while women were the dancers. Being music for the court, musicians and dancers were from the Malay race. Social changes that took place include females and musicians from different races playing the gamelan, the gamelan being performed for the entertainment of the masses and being 'concertised', and new music being composed to accompany dance, dance drama and theatre.

\subsection{Playing techniques}

In contemporary gamelan music, various techniques have been applied to create a more diversified and unique sound of the gamelan. In addition to adding instruments, the use of different sounds and effects can be created by using different playing techniques. In traditional gamelan playing, notes need to be damped on certain instruments, such as the saron family, so that the sounds of played notes do not resonate in the subsequent phrases. This is done by damping (holding the edge of a bar) the particular note that has just been played simultaneously as the next note is played to create a continuous effect except where there are rests in the music. Different effects on the gamelan can be created by changing the technique of damping. For example, to create a short muted sound, the bar or knobbed gong can be damped as the same note is being struck. Alternatively, when striking a bar or a knobbed gong, the note can be damped without lifting the mallet once struck. Shorter note values can be created by damping the notes immediately after the note is played.

New compositions also demand a higher level of playing skills and dexterity on the part of the players to be able to manipulate the playing technique and speed that may be required of certain pieces. Composers also tend to change the technique of playing gamelan instruments for manipulation of speed, to create harmony, or to get a certain sound. Quick changes of mallets, harder and louder sound levels, fast-moving melodic lines, and complex rhythmic patterns are the norm in these compositions.

The use of double mallets for instruments that typically use one mallet to play is commonly employed in new music. Different types of mallets used in the various types of Indonesian gamelan can also be used to create a particular sound as well. An example of this is the hardwood Balinese gamelan mallet which produces a hard and sharp sound. Percussion mallets such as the marimba or xylophone mallets are also used. The Balinese mallet is also used when playing Balinese style pieces on the Malay gamelan.

In creating new ways of playing the Malay gamelan and creating sounds, composers are looking at having two players as instruments. This can be done on the bonang whereby two players can either sit opposite to each other or on the same side of the instrument. Depending on the line written for the instrument, more than one player has also been used to play the gambang, gong and kempul, and kenong. The sound produced by musicians in the context of composition is another point of consideration. Generally, a gentle tone is produced when playing traditional repertoire. However, composers these days are experimenting with different touches, such as creating hard or soft performance styles on the gamelan instrument (Matusky, 2008).

Other composers and gamelan groups are also experimenting with the use of new tone colours such as using non-gamelan instruments like the voice or a group of voices, ethnic and western percussion instruments, seruling, electric guitar, electric bass, cello, violin, and flute and the gamelan which allows for richer melodic lines and harmonisation, thus making gamelan music more diversified than the traditional repertoire.

\subsection{Compositional methods}

In addition to using different playing techniques, some composers are using their experience and knowledge of Indonesian gamelan traditions in the context of Malay gamelan music, maintaining the traditional style in new compositions or simply creating new compositions. While this may not easily be adapted in the school curriculum without any knowledge of the two traditions, the use of new tone colours that are being experimented with can easily be adapted. Non-gamelan instruments like the voice or a group of voices, ethnic percussion instruments, electric guitar, electric bass, cello, violin, flute, western percussion Instruments, which are readily accessible, can be used as melodic or rhythmic instruments in this way as well.

In certain compositions, the combination of instruments and musical collaborations reflect the cultural diversity of Malaysia. Tan Sooi Beng's compositions reflect Malaysia's multiethnic society. Perubahan is an example of a composition that signifies change and advocates a Bangsa Malaysia (Malaysian race) through the use of the gamelan, Shigu drums, Malay drums and rhythmic patterns of the 24 Season Drum ensemble and Kelantanese shadow play. Current practices in Malay gamelan music also allows the learning of music from other cultures across the world when elements of the music are integrated into the new composition.

\subsection{Discussion}

Several implications for music education arise in view of the developments which have and still are taking place. In developing a structured method of teaching the gamelan, it is still very important that certain aspects of teaching retain traditional teaching methods to avoid unsatisfactory developments of the music (Supanggah, 2008). Students need to first understand the characteristics which define 
the Malay gamelan and learn traditional playing techniques and repertoire as a basis for playing the gamelan before learning new compositions (Shahanum \& Adam, 2016). This is to ensure that students have a foundation to understand traditional music and to be able to produce or recreate new music.

As an aural tradition, learning the gamelan among court musicians was by listening, observing and playing. The transfer of skills and knowledge was carried out orally within the community of musicians. Subsequently, when the Malay gamelan was taken out of the purview of the royal courts in the 1960s, the repertoire was notated using cipher notation for preservation. With the advent of formal music education in schools, notation is now being used. New pieces for the gamelan would mean a reliance on the score as the parts would be written out for each instrument as opposed to traditional repertoire, which provides the skeleton melodic framework. In teaching new compositions for the gamelan, it would still be necessary for students to develop aural awareness even with the use of notation.

If teachers do not have the means of getting different mallets for different sound effects, they can also experiment with different ways of producing sounds with gamelan mallets or use different parts of the instrument to create sounds. Teachers can also combine whatever available non-gamelan instrument to the ensemble to create a wider range of sound combinations and tone colours. Combining instruments of other ethnic groups can also add the extra dimension of reflecting cultural diversity.

Given the nature of the art form and the semi-improvisatory style of the gamelan, it is suggested that the non-formal method of transmission actually be applied to teaching the gamelan as it will help students develop their listening and aural abilities as well as an awareness of playing in an ensemble. The notation could be used as a working guide to provide the framework of a piece. An understanding of the function of each instrument will allow the musician to elaborate the lines according to the instrument played. This method could also be an exercise to expand the students' creativity when used to teach composition and improvisation. Composition projects using gamelan instruments and other musical instruments or sound mediums should also be included as classroom activities. The abovementioned techniques used by composers can readily be adapted to the classroom.

\subsection{Conclusion \& Recommendations}

The changes in the musical style, repertoire content and attitudes toward the gamelan can be related to changes in the Malaysian culture or society and to changes in the ideas held by the people and the meanings they assign to their culture. The innovations taking place need to be taken into the classroom as a method of revitalising and preserving tradition and also to promote national unity through the education system. Changes need to be made to the music curriculum where the gamelan is concerned to make learning the gamelan more interesting and relevant to students in these changing times and to broaden the horizons of students. Schools can help act as an agent for change and innovations to occur.

Evaluation and innovation of teaching methods need to be constantly made to adapt to the aesthetical and socio-cultural demands and requirements which accompany the changes in each new era. A compromise and a combination of various teaching systems are needed. The teaching methodology, choice of teaching material must be reviewed to support these changes. Teachers will also need to equip themselves with a wide repertoire of knowledge to deal with the new material and methods to teach the gamelan and use the gamelan to teach music.

\section{References}

Englis, F. (2003), Integrating non-western and western Music: An innovation in music teaching and music-making, Malaysian Music Education Conference 2003, Shah Alam, Malaysia.

Matusky, P. \& Tan, S. B. (1997), Muzik Malaysia: Tradisi klasik, rakyat dan sinkretik. The Asian Centre, Pulau Pinang.

Matusky, P. Y. (2008), Aspects of basic instrumentation and traditional form of the repertoire of Malay Gamelan and the challenge of repertoire expansion, World Gamelan Symposium and Festival, Terengganu, Malaysia.

Nasuruddin, Mohd. Ghouse. (1994). Tarian Melayu. Kuala Lumpur: Dewan Bahasa dan Pustaka

Supanggah, R. (2008), Pengalaman mengurus, memperlengkap dan memperluas kaedah pengajaran seni di Sekolah Tinggi Kesenian Indonesian pengkhususan seni muzik dan tari gamelan, World Gamelan Symposium and Festival, Terengganu, Malaysia.

Shahanum, M. S. \& Mohamad Adam Masumi. (2016), Teaching traditional music in Malaysian schools: Considering the cultural context, International Journal of Learning and Teaching, 8 69-76.

Tan, S. B. (2008) Perkembangan dan pergerakan penggubahan muzik gamelan di Malaysia masa kini, World Gamelan Symposium and Festival, Terengganu, Malaysia. 